\title{
Non-relational conditions necessary for mentoring of black small business owner-managers in South Africa
}

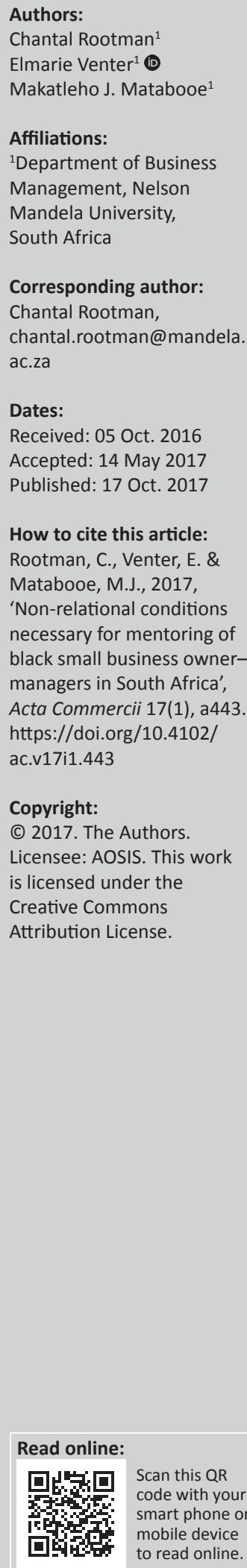

Orientation: This study focuses on effective mentoring of black small business ownermanagers. It aims to gain an understanding of non-relational conditions necessary for the mentoring of their businesses.

Research purpose: To identify non-relational-based conditions for effective mentoring of black small business owner-managers. Effective mentoring can help enhance business management skills and improve the survival of small businesses in South Africa.

Motivation for the study: Previous research on mentoring mainly focused on relational conditions required for mentoring. It is equally important to investigate non-relational conditions required for mentoring and provide recommendations to help achieve effective mentoring of small business owner-managers.

Research design, approach and method: An interpretivism paradigm and qualitative research methodology were followed. The experiences of participants were obtained through semistructured interviews.

Main findings: Conditions surrounding the accessibility of the mentoring location, accessibility of mentoring resources, capacity of mentors, financial support, marketing strategies and practical arrangements for the mentoring process are essential during mentoring of black small business owner-managers.

Practical and managerial implications: Investigating the experiences of mentors, mentees and board members or managers provides insight into non-relational conditions required for effective mentoring of black small business owner-managers. Recommendations are provided to help enhance mentoring facilities and ultimately the success and longevity of small businesses.

Contribution and value-add: Knowledge of non-relational conditions required for effective mentoring could result in successful skills development of owner-managers. Ultimately, the decision-making of owner-managers could be improved, and the success and longevity of their businesses could be enhanced.

\section{Introduction and background to this study}

In South Africa, the small and medium-sized enterprise (SME) sector is one of the largest contributors to the country's economy (Adeniran \& Johnston 2012:4088; Smit \& Watkins 2012:6325). Nonetheless, these businesses do not reach their full potential and fail to grow, resulting in job losses and decreased wealth for the country (Fatoki 2011:193; Neneh 2012:3365). This failure has implications not only for economic growth and employment but also for the wealth and health of the owner-managers (Gallato et al. 2012:2). A lack of business management skills possessed by the owner-managers is often described as one of the major impediments that inhibit the survival of small businesses (Chimucheka \& Mandipaka 2015:311; Gallato et al. 2012:2; Smit \& Watkins 2012:6325). It could have negative implications for businesses when ownermanagers do not have the necessary skills to make profound decisions because decision-making in small businesses is, to a large extent, owner-centred (Xavier \& Martins 2011:91).

In an effort to improve the business management skills of small business owner-managers, and in turn the survival of their businesses, many initiatives and institutions were put in place by the South African government to nurture the SME sector (Adeniran \& Johnston 2012:4089; Brière, Tremblay \& Daou 2015:713; Smit \& Watkins 2012:6325). Nonetheless, these initiatives seem to be failing considering that the development of small businesses in South Africa still remains a challenge (Irwin 2011:210). A different strategy is therefore needed to specifically focus on the 
development of owner-managers (Parak \& Khonje 2012:27), which will in turn improve the survival of their businesses.

Consequently, a strategy such as mentoring could provide business owner-managers with opportunities that focus on developing their own managerial and entrepreneurial skills (Botha \& Esterhuyzen 2012; Kengne 2015:123). Cline (2011:31) advises that managerial skills are essential for the success of small businesses, including those in Africa, as small businesses on the African continent are challenged to compete within an increasingly competitive and global economy. Effective mentoring could be a possible solution to enhance African small businesses' competitive behaviour and overall competitiveness because effective mentoring in a business improves managerial skills (Herholdt 2012; Lo \& Ramayah 2011:428; Offstein, Shah \& Gnyawali 2011:79). In addition, the use of mentoring could help create and refine knowledge of small business owner-managers to use in making business decisions (Chandra \& Aneja 2004:156; Herholdt 2012; Offstein et al. 2011:79). However, even though research (Botha \& Esterhuyzen 2012:12102; NEF Annual Report 2014) shows that small business owner-managers in South Africa enrol for mentoring programmes to improve their management skills and ultimately their businesses' survival, these businesses still fail. This raises concerns about the effectiveness of mentoring programmes available for small businesses (Brière et al. 2015:713; NEF Annual Report 2014).

Gosh (2014:368) asserts that previous research on the antecedents of mentoring is scattered which makes it challenging to understand the conditions required for effective mentoring support. Furthermore, most studies that were carried out to identify conditions required for effective mentoring focused on mentoring relationships (e.g. Distelberg \& Schwarz 2015; Eller, Lev \& Feurer 2014; Ensher \& Murphy 2011). Therefore, this study aims to investigate non-relational conditions required for effective mentoring of black small business owner-managers in South Africa. Insight into these conditions could help guide mentors and mentoring institutions to maximise the outcomes during mentoring of black small business owner-managers.

This study focuses on black-owned small businesses because the future of the South African economy depends on enhancing the black population's involvement in entrepreneurship (Preisendörfer, Bitz\& Bezuidenhout2012:5). However, improving these businesses remains a major challenge facing the South African economy (Rogerson 2013:141), and the development of these businesses has been characterised by slow growth (Nyazema 2013:64). Furthermore, black owner-managers are often not sufficiently educated to be entrepreneurs (Ndedi 2013:197). Given their background, black small business owner-managers might not have had the same educational and training opportunities as small business owner-managers from other racial backgrounds (Nkosi, Bounds \& Goldman 2013), which could negatively impact the development of their businesses. In addition, the black community has a low participation rate in entrepreneurial activities compared to other racial groups (Nkosi et al. 2013:2; Preisendörfer et al.
2012:2), yet this population is the largest in South Africa, representing 79.4 per cent of the population (Lucassen et al. 2013). Therefore, this study focused on whether black small business owner-managers reflect the literature in terms of the non-relational conditions necessary for effective mentoring.

\section{Purpose and primary objective}

The purpose of this study is to identify the most important non-relational conditions necessary for effective mentoring of black small business owner-managers. Identifying these conditions is essential as proper mentoring structures could be created to ensure effective mentoring for small businesses in general, and of black small business owner-managers in particular. Through the effective mentoring of these ownermanagers, their business management and decision-making skills could be enhanced and eventually the survival of their businesses will be improved. The literature provides ample research on small businesses in general; however, research on mentoring of small businesses is limited (Clutterbuck \& Abbott 2012:74; McKevitt \& Marshall 2015:264). Therefore, the primary objective of this study is to gain an understanding of non-relational conditions required for effective mentoring of black small business owner-managers.

\section{Literature}

\section{Nature and importance of mentoring for skills development in small businesses}

The concept of mentorship originates in Greek mythology. During this time, Odysseus, the king of Ithaca who fought in the Trojan wars, placed Mentor in charge of his son Telemachus while he was away from home. Mentor was to see to Telemachus's education and the development of his identity into adulthood (St-Jean \& Audet 2012:122; Terblanché 2011:55). Odysseus was gone for 20 years, during which Telemachus matured into a wise and confident man under the guidance of Mentor (Rombeau 2010:89). Since then, the term 'mentor' has been used over time to demonstrate a characteristic of a trusted advisor, friend and teacher (Gentry, Weber \& Sadri 2008:241; Rombeau 2010:89). Therefore, mentoring is defined as a relationship between two parties, where one of these passes on knowledge about a specific subject to the other party (Cline 2011:36).

Mentoring is about making a difference in the effective development of managers to nurture them and make them future leaders (Freedman 2009:171), which is important considering the high failure rate among small businesses. Durbin (2016:78) states that one of the benefits of mentoring is that it develops people and encourages them to be successful. That is, people are able to meet a range of competing demands because mentoring provides an opportunity for mentees to build confidence in dealing with challenges by developing new skills and expertise (Ayinde 2011:7). As such, mentoring of managers helps to create and refine knowledge of the competitive environment, thereby assisting them to use such knowledge in making effective strategic decisions (Offstein et al. 2011:77). 
Rankhumise and Lehobye (2012:5601) assert that small business owner-managers often do not come from the field of business. Therefore, business mentoring is essential because it allows for the transfer of business skills that may not have otherwise been acquired (Allen et al. 2009:1117). At the same time, mentoring could provide owner-managers with opportunities that focus on developing managerial and entrepreneurial skills (Botha \& Esterhuyzen 2012). As such, owner-managers would be able to learn management skills through action, with the support of a person with extensive business experience (Cline 2011:35).

Owner-managers need to have someone who can challenge their thinking and encourage them to explore alternative perspectives on how they do things in order to improve the survival of their businesses. Therefore, given the important role of mentoring in developing people, owner-managers should be able to perform at an improved level by engaging in mentoring programmes (Oluwatoyin 2011:169). Furthermore, when small businesses engage in mentoring, potential skills of owner-managers can be developed to enhance the performance of these businesses (Cline 2011:36). Lastly, mentoring can be extended to maximising the competitiveness of businesses (Oluwatoyin 2011:178; Zoogah 2013:30) and continuing growth through succession planning as part of mentoring (Fajana \& Gbajumo-Sheriff 2011:425). In doing so, potential future leaders of small businesses can be prepared for a smooth transition from one generation of ownermanagers to the next in order to ensure continuity and survival of these businesses.

\section{Skills required for a successful small business}

In the context of South Africa, some individuals go into business because of the high unemployment rate facing the country, yet they do not acquire proper skills to operate a business (Rankhumise \& Lehobye 2012:5601). As mentioned earlier, this is even more true in the case of black-owned small businesses because of the historically disadvantaged background of the black population in South Africa (Miles 2013:4), where some start businesses as a way out of poverty (Nyazema 2013:64). Black-owned businesses also often experience a lack of business management skills because of limited education and training opportunities for the ownermanagers, in comparison to small business owner-managers from other racial groups (Nkosi et al. 2013:2). Many black people in South Africa were either employed in the public sector or unemployed before the democratic transition that took place in South Africa in 1994 (Ndedi 2013:197). This implies that the black community was often not involved in entrepreneurial activities and therefore was not offered the opportunity to develop their business management skills. This is why black business empowerment is one of the priorities of the South African government to promote equality in South African communities (Horwitz \& Jain 2011:298).

Of the many skills that small business owner-managers need in order to operate their businesses efficiently and effectively, those that are commonly suggested are: technical, marketing, financial and human resource skills (Bezuidenhout \& Nenungwi 2012; Mutanda, De Beer \& Myers 2014; Nkosi et al. 2013; Thwala \& Mvubu 2008). Even though skills development is needed for small businesses, it should be noted that the skills needed differ across industries (McFarland \& McConnell 2012:104; Nkosi et al. 2013:2) and become more specialised as a business grows (McFarland \& McConnell 2012:104). For example, small businesses consist of industries such as technology, manufacturing and agricultural industries [Small Enterprise Development Agency (SEDA) 2012:88], which means that skills gaps across these industries may differ. As such, it is important that the skills development programmes for small businesses are tailored to meet the specific needs of the various industries in the small business sector (Bezuidenhout \& Nenungwi 2012:11659).

\section{Conditions necessary for effective mentoring}

The literature across multiple disciplines has revealed numerous conditions commonly found in an effective mentoring programme. These include conditions necessary to enhance the personal interaction between mentors and mentees during the mentoring process (see Distelberg \& Schwarz 2015:193), as well as the conditions that are necessary to facilitate mentoring processes (Botma \& Roets 2013:37). As this study focuses on non-relational conditions of mentoring, these refer to those conditions which do not impact the personal relationship of the mentor and mentee, but rather impact the mentoring process itself.

Botma and Roets (2013:37) as well as Distelberg and Schwarz (2015:195) assert that having resources available for the mentoring process is essential for effective mentoring. These resources might be related to the necessary infrastructure as well as financial resources needed for mentoring to take place. Examples of infrastructure include the location at which the business is situated, roads, water supplies, electricity supply, communication networks and technology (Battisti et al. 2013:74; Mbonyane \& Ladzani 2011:553; Modiba, Kotzé \& Eloff 2012:123; Olawale \& Garwe 2010:731). The lack of these infrastructural facilities might hinder effective mentoring, and is therefore a challenge that inhibits the growth prospects of small businesses (Olawale \& Garwe 2010:732; Ongori \& Migiro 2010:97). In their study on satellite networks, Tang et al. (2014) found that technology facilities through the use of satellite are essential to achieve effective mentoring. The discussion above shows that appropriate infrastructure is important for effective mentoring to occur. The financial stability of mentoring institutions during mentoring processes is another important aspect relating to the effectiveness of mentoring programmes (Botma \& Roets 2013:37). This includes the ability of mentees to pay for fees and materials necessary for mentoring services (Distelberg \& Sorenson 2009:71).

Determining the length and frequency of mentoring sessions, as well as developing a clear system on how mentors and mentees are matched is advised for effective 
mentoring (Slack et al. 2013:3). The study of Copeland and Calhoun (2014:40) confirms that mentoring sessions that are clearly designed have an impact on the effectiveness of mentoring processes. These authors explain that mentoring sessions should include scheduled meetings with specific topics.

As can be deduced from the literature review, numerous nonrelational conditions are necessary to ensure effective mentoring. Therefore, in an attempt to enhance effective mentoring of black small business owner-managers, the following research questions are presented:

What are the non-relational conditions necessary to ensure effective mentoring of black small business owner-managers, based on the experiences of mentors, mentees and board members or managers?

What guidelines and recommendations on non-relational conditions can be put forward to help mentoring institutions, as well as other stakeholders, to achieve effective mentoring of black small business owner-managers?

\section{Research paradigm and methodology}

An interpretivism paradigm was adopted in this study. The interpretivism paradigm is appropriate when the researcher tries to uncover and describe meanings of a phenomenon as it is understood by an individual or a group of individuals (Bryman \& Bell 2011:16-18). Because the interpretivism paradigm is often associated with qualitative research methodologies, a qualitative research methodology was adopted.

According to Zikmund et al. (2013:139), there are several methods to choose from when following a qualitative research methodology. A phenomenological method of research is followed in this study. Phenomenology is a study of how things are perceived based on individual experiences and the meanings that these things have in these experiences (Zikmund et al. 2013:136).

Even though mentoring is popular for its use as a developmental tool, little information exists on mentoring for small business in South Africa (Clutterbuck \& Abbott 2012:74). Therefore, in order to gain an understanding of non-relational conditions required for effective mentoring of black small business owner-managers, exploratory research was considered most appropriate. Exploratory research enables researchers to understand the lived experiences of participants and the meanings participants make about such experiences (Young \& Atkinson 2012:51). For this study, through exploratory research, the participants' experiences would help identify non-relational conditions necessary for effective mentoring so that recommendations can be put forward that could help achieve effective mentoring of black small business owner-managers.

\section{Sampling}

This study aimed to identify potential participants from all those black small business owner-managers in South Africa who have participated or are currently participating in a mentoring programme.

Specifically, purposive convenience and criterion sampling (Collis \& Hussey 2014:132; Struwig \& Stead 2015:127-130) were used to select the sample for the study. From a database developed by the SEDA, the researchers identified institutions providing mentoring to small businesses. In total, four institutions were willing to participate in the study and supply their mentees' details. These institutions were contacted via email and telephone, and requested to provide contact details of black small business owner-managers who have participated in or who are currently participating in a mentoring programme. After the selection of the mentees, representing different industries, a group of mentors (linked to the identified mentees) and finally a group of board members or managers (based on willingness) were selected.

In total, 21 people linked to the mentoring institutions participated in this study: 12 mentees, 6 mentors and 3 board members or managers.

\section{Data collection}

Data were collected through semi-structured interviews. These interviews enabled the researchers to gain an in-depth understanding of non-relational conditions required for effective mentoring of black small business owner-managers. Using semi-structured interviews other related topics may emerge during the conversation, while at the same time the pre-formulated questions provide focus and a measure of consistency to the discussion (Myers 2013:125). In this study, all interviews were conducted in English and were captured on an audio tape recorder to be transcribed verbatim. Interview questions included, but were not limited to, the following:

- How often do mentors meet with mentees?

- Where do they have meetings?

- How long is the mentorship programme?

- Is there a financial subsidy that is provided to mentees for the mentoring programme?

- Are there any challenges to successful mentoring of small business owner-managers?

- Generally, what do you perceive as the contributing conditions to a successful or failed mentoring process?

\section{Data analysis}

According to Clutterbuck and Abbott (2012:74) as well as McKevitt and Marshall (2015:264), little is known about the conditions necessary for mentoring programmes for small business owner-managers, and therefore of black small business owner-managers. As such, a combination of deductive and inductive coding methods was adopted for this study. This study is based on gaining greater insight into 
non-relational conditions required for effective mentoring of black small business owner-managers. Therefore, it is focused on reading data to develop themes and sub-themes (inductive codes). Themes and sub-themes from the literature (deductive codes) were also considered. Thus, inductive codes were used as a starting point to identify themes and sub-themes in the data. Thereafter the themes and subthemes that were similar to the literature were merged and adopted in this study.

The coding framework that was adopted in this study is the Tesch's model, as described in a study by De Vos et al. (2002:340-341). Following the Tesch's model in this study, the transcripts were first read for each group of participants. This enabled the researchers to identify words and phrases that were common to each group. While trying to understand the information contained in the transcripts, thoughts and ideas were written down as they came to mind. The topics that were common from these transcripts were categorised together and placed next to the relevant words or phrases in the transcripts. A further analysis was made on these words and phrases to discover any underlying themes and subthemes to simplify the coding process. To enable a preliminary analysis themes and sub-themes were grouped into relevant categories for comparison of differences in the perceptions and experiences across the three groups of participants.

A combination of content and constant comparative analysis was used to analyse the data. Content analysis was performed to find meaning of the transcribed interviews (Stam 2008:26), while constant comparative analysis was used to identify similarities and differences among the three groups of participants (Shi 2008:158). The variations across the three groups of participants provided an understanding of nonrelational conditions that are necessary to ensure effective mentoring of black-owned small businesses in South Africa.

\section{Trustworthiness}

Trustworthiness is a concept that assesses the issue of rigour of qualitative research (Elo et al. 2014:2). According to Struwig and Stead (2015:137) four concepts are important in qualitative research to ensure trustworthiness, namely credibility, dependability, confirmability and transferability.

Credibility of the findings (Struwig \& Stead 2015:137) was ensured by receiving participants' feedback on the data collected. This was done to confirm that the information recorded was accurate and correct. Dependability of this study (Collis \& Hussey 2014:172) was ensured as the researchers constructed a thorough and well documented methodology section. In addition, proper documentation of all the important information pertaining to this study was done which included the interview schedule, interview transcripts and other secondary data for future reference. To enhance confirmability in this study (Collis \& Hussey 2014:172), all interviews were audio taped and transcribed to ensure that the responses were recorded correctly. After this, these records were archived to be available should the findings of this study be challenged. Concerns regarding transferability (Elo et al. 2014:2) were addressed by comparing the empirical findings of this study with previous research on mentoring in other contexts.

\section{Ethical consideration}

Ethics approval (H14-BES-BMa-067) was obtained by the researchers from the academic institution at which this study was conducted. Participants were briefed on the reason and format of the interviews by means of a short introduction. They were further given the opportunity to decline participation in the study. Lastly, the participants were assured that the information they provided would be treated with the strictest confidentiality.

\section{Findings}

The findings of this study might be applicable to the nonrelational conditions necessary for effective mentoring of small business owner-managers in general. However, this study focused on black small business owner-managers' experiences, as well as those of their mentors and institutions' board members or managers, with regard to non-relational conditions necessary for effective mentoring. Therefore, the findings and recommendations of this study should be interpreted within this context.

Table 1 provides a summary of the themes and quotes that illustrate the non-relational conditions necessary for effective mentoring of black small business owner-managers in South Africa.

\section{Accessibility of mentoring location}

Accessibility of the mentoring location was noted as important for effective mentoring. In particular, mentor and mentee participants highlighted accessibility of the mentoring location as significant, noting that the location of the places providing mentoring to small business owner-managers was not easily accessible. Mentors reported that 'the centre is away from, [laughter] from civilisation' (Mentor 4, female, 36) which explains 'a decrease in attendance' (Mentor 4, female, 36) during mentoring sessions. In addition, mentors explained that the 'roads are not well' (Mentor 2, male, 55) and that 'some of them [mentees] have to depend on transport [public transport]' (Mentor 6, male, 74). Therefore, 'they are not always on time' (Mentor 6, male, 74). Similarly, mentees reported that 'the place [mentoring location] is very much awkward' (Mentee 4, male, 37) and that it is a challenge for them to 'reach this place' (Mentee 4, male, 37) perhaps because the mentoring location is 'quite a distance out' (Mentee 12, female, 30).

\section{Accessibility of mentoring resources}

The importance of accessibility of mentoring resources for effective mentoring was highlighted across the three groups of participants. Mentors indicated that to some extent, they could not provide mentoring because mentees 'don't even have access to emails' (Mentor 4, female, 36). One mentor was 
TABLE 1: Themes and quotes that illustrate the non-relational conditions required for effective mentoring of black small business owner-managers.

\begin{tabular}{|c|c|c|c|}
\hline Themes & Mentors' quotes & Mentees' quotes & Board member or managers' quotes \\
\hline $\begin{array}{l}\text { Accessibility of } \\
\text { mentoring location }\end{array}$ & $\begin{array}{l}\text { - 'the centre is away from, [laughter] from } \\
\text { civilisation...' (Mentor 4, female, 36) } \\
\text { - 'roads are not well' (Mentor 2, male, 55) } \\
\text { - 'some of them [mentees] have to } \\
\text { depend on transport [public transport]...' } \\
\text { (Mentor 6, male, 74) }\end{array}$ & $\begin{array}{l}\text { - 'the place [mentoring location] is very much } \\
\text { awkward' (Mentee 4, male, 37) } \\
\text { - 'quite a distance out...' } \\
\text { (Mentee } 12 \text {, female, 30) }\end{array}$ & - \\
\hline $\begin{array}{l}\text { Accessibility of } \\
\text { mentoring resources }\end{array}$ & $\begin{array}{l}\text { - 'they [mentees] don't even have access to } \\
\text { emails...' (Mentor 4, female, 36) } \\
\text { - 'I think (name of institution withheld) did not } \\
\text { provide a huge amount of resources...to } \\
\text { them, it was a Mickey Mouse thing. It ran } \\
\text { on the side-line...it's not important to them - } \\
\text { it's low on the agenda'. (Mentor 3, male, 66) } \\
\text { - 'computers are not working, they are not } \\
\text { operating' (Mentor } 1 \text {, male, 22) }\end{array}$ & $\begin{array}{l}\text { - 'If you teach someone...you teach me } \\
\text { bookkeeping - yes, it's good, but there's a } \\
\text { resource that you have to provide me so } \\
\text { that I can cope...' (Mentee 5, male, 55) }\end{array}$ & $\begin{array}{l}\text { - 'you find that they [mentees] don't respond to } \\
\text { emails because they have to go to an internet } \\
\text { café to open the emails...' (Board member or } \\
\text { manager 1, female, 28) }\end{array}$ \\
\hline $\begin{array}{l}\text { Capacity of } \\
\text { mentors }\end{array}$ & - & $\begin{array}{l}\text { - 'we attend as a group....don't have enough } \\
\text { people or mentors in the centre', (Mentee 4, } \\
\text { male, 37) } \\
\text { - 'you can't see your mentor because } \\
\text { they are booked for the whole day...' } \\
\text { (Mentee 3, male, 24) }\end{array}$ & $\begin{array}{l}\text { - 'I also play that role [mentor]...we are on a drive } \\
\text { to try and identify and get more mentors... } \\
\text { remember it's also a cost challenge...nobody } \\
\text { wants to mentor for free'. (Board member or } \\
\text { manager 2, male, 42) } \\
\text { - '...we're using one external and then myself'. } \\
\text { (Board member or manager 3, male, 51) }\end{array}$ \\
\hline Financial support & $\begin{array}{l}\text { - 'we can't obviously do all of the skills } \\
\text { identified...due to obviously funding issues...' } \\
\text { (Mentor 4, female, 36) } \\
\text { - 'Every training that we provide obviously } \\
\text { needs to be paid, but obviously there has to } \\
\text { be funds for it...' (Mentor 4, female, 36) }\end{array}$ & - & $\begin{array}{l}\text { - 'the amount of funding that's made available..., } \\
\text { the amount of grand funding [is insufficient]...' } \\
\text { (Board member or manager 2, male, 42) } \\
\text { - 'They [mentees] don't have the money to pay } \\
\text { the internet café...' (Board member or manager } \\
\text { 1, female, 28) }\end{array}$ \\
\hline Marketing strategies & $\begin{array}{l}\text { - 'I don't really know of any state organisation } \\
\text { that's promoting it [mentoring]...' (Mentor 3, } \\
\text { male, 66) } \\
\text { - 'I stay very close to this area but I was not } \\
\text { even aware of [mentoring institution], I think } \\
\text { publicise more of this information...the } \\
\text { institutions themselves'. } \\
\text { (Mentor 4, female, 36) }\end{array}$ & $\begin{array}{l}\text { - 'this programme [mentoring programme] } \\
\text { must be made known to the people' } \\
\text { (Mentee } 9 \text {, male, } 54 \text { ) } \\
\text { - 'the government should find other } \\
\text { ways...spread the word [about mentoring } \\
\text { institutions]' (Mentee } 12 \text {, female, 30) } \\
\text { - 'I have never heard about it [mentoring } \\
\text { institutions] on TV, I've never come across } \\
\text { it in a newspaper...' (Mentee } 12, \text { female, 30) }\end{array}$ & - \\
\hline $\begin{array}{l}\text { Practical arrangements } \\
\text { for the mentoring } \\
\text { process } \\
\text { - mentor-mentee } \\
\text { matching } \\
\text { - scheduling of } \\
\text { meetings } \\
\text { - structuring of } \\
\text { mentoring sessions }\end{array}$ & $\begin{array}{l}\text { - 'the requirement [for a meeting] is always } \\
\text { on the mentee...' (Mentor } 3 \text {, male, 66) }\end{array}$ & $\begin{array}{l}\text { - 'I would prefer to choose the mentor myself'. } \\
\text { (Mentee 9, male, 54) } \\
\text { - 'We don't have a date like when we are } \\
\text { supposed to meet...' (Mentee } 8, \text { male, 41) } \\
\text { - 'I prefer one-on-one [mentoring sessions]' } \\
\text { (Mentee 4, male, 37) } \\
\text { - 'we are in actually in different type of } \\
\text { industries' (Mentee 4, male, 37) } \\
\text { - 'in group, sometimes he [mentor] can't } \\
\text { reach us all'. (Mentee 5, male, 55) } \\
\text { - 'in a group, you learn more', 'it [group session] } \\
\text { just equips you with more information'. } \\
\text { - 'Mentee } 12 \text {, female, 30) } \\
\text { - 'Mentent levels of small businesses' } \\
\text { - 'want to relate' (Mentee 7, male, 25) }\end{array}$ & - \\
\hline
\end{tabular}

quoted saying: 'I think [name of institution withheld] did not provide a huge amount of resources ... to them, it was a Mickey Mouse thing. It ran on the side-line ... it's not important to them - it's low on the agenda' (Mentor 3, male, 66). Mentors further stated that the computers which mentees should be using at the institutions 'are not working, they are not operating' (Mentor 1, male, 22). One mentee pointed out that mentoring 'resources' should be provided to ensure success during the mentoring process. He said: 'If you teach someone ... you teach me bookkeeping - yes, it's good, but there's a resource that you have to provide me so that I can cope' (Mentee 5, male, 55). One board member or manager mentioned that it had come to the institution's attention that some mentees did not have access to the facilities necessary for mentoring because 'you find that they don't respond to emails because they have to go to an internet café to open the emails' (Board member or manager 1, female, 28).

\section{Capacity of mentors}

Mentee and board member or manager participants indicated that mentoring sessions are conducted in group settings as there are too few mentors to facilitate individual mentoring. Mentees mentioned that they 'attend as a group ... don't have enough people or mentors in the centre' (Mentee 4, male, 37), and that in most cases 'you can't see your mentor because they are booked for the whole day' (Mentee 3, male, 24). In some cases, the board members or managers also assisted in the mentoring sessions when not enough mentors were available. One board member or manager acknowledged this, pointing out that increasing the capacity of mentors is costly because 'nobody wants to mentor for free' (Board member or manager 2, male, 42). Another board member or manager emphasised the limited capacity by stating that 'we're using one external and then myself' (Board member or manager 3 , male, 51).

\section{Financial support}

The significance of financial support during a mentoring process was acknowledged by one mentor and board member or manager. One mentor reported that a lack of funds was hindering the effectiveness of the development support they provide to small businesses. This mentor revealed that they 
could not provide mentees with enough training and advice 'due to obviously funding issues ... there has to be funds for it' (Mentor 4, female, 36). Interestingly, mentees did not comment on the importance of financial support for the success of mentoring processes. Rather, they emphasised that mentoring institutions 'should be more assisting with day-today running of companies [their own businesses]' (Mentee 3, male, 24) and that mentoring institutions should provide mentees with capital because 'it's not easy to build your capital' (Mentee 8, male, 41). Mentees also indicated that 'access to finance is the biggest thing [challenge]' (Mentee 7, male, 25) and that even for the little money that is available to small businesses it is yet another challenge 'to get a hold of those opportunities' (Mentee 10, female, 40). The board members or managers emphasised that there was insufficient funding available to ensure the effective mentoring of small businesses. For example, the board members or managers explained that 'there's always challenges. ... For instance, it's the amount of funding that's made available ... the amount of grand funding [is insufficient]' (Board member or manager 2, male, 42). These participants further indicated that mentees 'don't have the money to pay the internet café' (Board member or manager 1 , female, 28 ) in order to access emails.

\section{Marketing strategies}

The mentor and mentee participants were of the view that the development support available to small businesses through mentoring programmes should be known to the public in order to have successful mentoring programmes. One mentor noted that he does not 'know of any state organisation that's promoting it [mentoring]' (Mentor 3, male, 66). The Another mentor also revealed that even though she lives close by to the institution, she 'was not even aware of [mentoring institution], I think publicise more of this information' (Mentor 4, female, 36). Similarly, some of the mentees stated that 'this programme [mentoring programme] must be made known to the people' (Mentee 9, male, 54) and that 'the government should find other ways ... spread the word [about mentoring institutions]' (Mentee 12, female, 30). These mentees even cited a few examples that they have 'never heard about it [mentoring institutions] on TV, I've never come across it in a newspaper' (Mentee 12, female, 30).

\section{Practical arrangements for the mentoring process}

There are three sub-themes that were reported by mentees as important relating to the practical arrangements for the mentoring process. The sub-themes are mentor-mentee matching, the scheduling of meetings and the structure of mentoring sessions.

Regarding mentor-mentee matching, it was noted that all mentee participants in this study engaged in a mentoring programme that 'was organised' (Mentee 6, male, 35) by the institutions. As such, the mentor-mentee process was structured by these institutions to address the needs of the mentees' businesses. However, these participants had contradictory views when asked about mentor-mentee matching preferences. Most of the mentees reported that they 'would prefer to choose the mentor myself' (Mentee 9, male, 54). Some of the reasons cited by mentees were as follows: 'I don't think my present mentor is really quite fine for the kind of work I'm doing' (Mentee 9, male, 54); 'I want somebody who can in a way, you know, guide me in the way I understand it' (Mentee 2, male, 52); 'I've got some expectations that I don't think anybody can just deliver' (Mentee 11, male, 49). Only two mentees indicated that they preferred the mentor to be 'organised' for them. They explained that 'if they [mentoring institutions] assess me, then they will choose somebody who is going to help me so much' (Mentee 6, male, 35).

Another aspect concerning the practical arrangements for mentoring processes is the scheduling of meetings. According to the participants, mentoring meetings are scheduled differently depending on the preference of the institution involved. Some of the participants indicated that the meetings were scheduled 'once a week' (Mentor 2, male, 55), 'twice a week' (Board member or manager 3, male, 51), 'every month' (Mentee 7, male, 25), while others stated that they 'don't have a date' (Mentee 8, male, 41). In some cases the participants indicated that 'the requirement [for a meeting] is always on the mentee ... the requirement on the programme was that they [mentees] had to set up the meeting' (Mentor 3, male, 66).

Still relating to the practical arrangements for mentoring processes, the structure of mentoring sessions is regarded to be important during the mentoring process. It was noted that mentoring sessions across the institutions that participated in this study were conducted 'in a group' (Mentee 4, male, 37). However, varied preferences were reported by mentees: some mentees indicated that they 'prefer one-on-one' (Mentee 4, male, 37) mentoring sessions, reasons being that their businesses are in 'different type of industries' (Mentee 4, male, 37) and that 'in group, sometimes he [mentor] can't reach us all' (Mentee 5, male, 55). Others indicated a preference for a group setting 'so that ... when other people ... ask some questions, then I can also gain' (Mentee 2, male, 52). This group of mentees further explained that businesses 'all go through the same, you go through similar problems' (Mentee 12, female, 30). Therefore, 'in a group, you learn more' (Mentee 12, female, 30), 'it [group session] just equips you with more information' (Mentee 12, female, 30). In addition, mentees highlighted the importance of homogeneity during mentoring sessions stating that there are 'different levels of small businesses' (Mentee 12, female, 30). For example, 'there are companies that are still starting out' (Mentee 3, male, 24) and there are also 'business already in operation' (Mentee 12, female, 30) yet 'we are all put under the same umbrella' (Mentee 3, male, 24). These mentees suggested that the different levels and phases of businesses should be used as a guide to address the needs of mentees, based on the life cycle stage of their businesses where ownermanagers can 'share' (Mentee 12, female, 30) and 'discuss similar problems' (Mentee 12, female, 30). Another group indicated that they preferred both styles of mentoring 
because they 'want to relate' (Mentee 7, male, 25) to what 'another entrepreneur is going through' (Mentee 7, male, 25) and at the same time one-on-one mentoring sessions are 'more in-depth ... you can make it personal about your company' (Mentee 3, male, 24).

\section{Discussion and recommendations}

The findings of this study reveal six key non-relational conditions which are essential to achieve effecting mentoring of black owner-managers in South Africa.

Even though the participants in this study reported that mentoring locations are not accessible, it was noted that accessibility of the mentoring location is important during mentoring of black small business owner-managers. According to the participants, it is important that the distance between mentoring institutions and mentees' businesses, as well as the distance that mentors must travel to reach these institutions and mentees' businesses, is as short as possible. A similar finding was observed by SEDA (2012:87) whose study reported that some of the SMEs operating in rural areas have to travel long distances to reach the institutions that support the development of these businesses. The mentioned study also revealed that SME advisors were reported as often having to travel long distances to reach the business premises of owner-managers. It should be noted that small businesses in South Africa are often situated in remote and rural areas and transport in and to these areas is a challenge as reported in this study. Poor infrastructure becomes even more challenging for the black community which is regarded as being the poorest racial group in this country, which means that having to incur transport expenses to get to mentoring locations may impact negatively on black owner-managers and their mentoring. As such, it is recommended that offices should be established and, if possible, branches within the area that they serve, particularly in the rural areas of the country. In addition, transport services could be provided to mentees. This can be achieved by deciding on a central location where mentees can be picked up and transported to and from mentoring institutions.

Access to mentoring resources such as training material necessary for mentors to facilitate mentoring processes, as well as to resources such as email facilities for mentees during mentoring processes, emerged as a challenge in this study. When mentors and mentees do not have the necessary mentoring resources, it is likely that mentoring will be ineffective. It is particularly important for black ownermanagers to have access to adequate resources as they may not be able to afford mentoring resources themselves. The empirical findings reported in this study correlate with previous research in respect of the lack of access to mentoring resources. For example, Jokelainen et al. (2011:2863) noted that even though a good relationship between mentors and mentees is an important aspect of a mentoring process, it is equally important to provide opportunities for mentoring with adequate resources to achieve effective mentoring. It is possible that one of the reasons for the institutions in the current study not providing mentors and mentees with the necessary mentoring resources is insufficient funding. This is confirmed by mentors' comments that they themselves often do not have access to training material, and that mentoring institutions do not provide enough resources for mentoring activities because there is insufficient funding for mentoring programmes. The participants also suggested that mentoring institutions do not provide enough resources to perform mentoring activities possibly because these institutions do not take mentoring seriously, and as a result do not provide sufficient resources for mentoring programmes. This may be a result of the fact that almost all the small businesses participating in this study were involved in technical activities, and that most of the funding is being used for technical activities rather than for business management skills development.

The findings of this study revealed that having enough mentors to address the individual needs of owner-managers in the various industries of the small business sector is important. The capacity of mentors refers to the number of mentors available to address the individual needs of ownermanagers during mentoring in the various industries of the small business sector. However, this was not the case during mentoring of the institutions that participated in this study as reported by the participants. As was the case with accessibility of mentoring resources, insufficient funding is given as a reason for not having enough mentors to facilitate mentoring to small business owner-managers. The findings of this study are corroborated by the findings reported by SEDA (2012:89) in which the limited capacity of mentors was reported as a challenge facing a large number of SMEs in South Africa. Therefore, the South African government, as well as those who provide mentoring facilities to small businesses, should ensure that they have enough mentors across the various industries of the small business sector to ensure effective mentoring of these business ownermanagers. The potential pool of mentors across the various industries of small businesses could be expanded by preparing competitive compensation packages for mentors.

Similar to the Mentoring and Befriending Foundation (2009:7), the majority of participants reported a lack of financial support for mentoring processes. Interestingly, mentees did not comment on the importance of financial support for the effectiveness of mentoring processes as one would expect that insufficient funding would have a significant impact on this group of participants. However, financial support for mentoring processes is important, according to both mentors and board members or managers, as it enables mentoring institutions to provide the necessary training to small business owner-managers. It is therefore recommended that there should be enough funding provided to mentoring institutions that will enable them to provide adequate mentoring support to small businesses. For example, mentoring institutions could develop strategies for generating more income themselves and not only be dependent on the government and private donors. Alternative financing options should be considered. Examples include 
establishing a policy for rental fees for those mentees who have been allocated space to operate their businesses on the mentoring institution premises. In addition, mentoring institutions could approach the new Ministry of Small Business about more funding and support to accommodate the needs of mentoring institutions.

It was reported in this study that many communities are not aware of skills development opportunities available to small businesses through mentoring programmes. This suggests that proper marketing strategies to promote the mentoring of small business owner-managers are necessary to ensure effective mentoring. Marketing strategies refer to the initiatives needed to make the public aware of mentoring services provided by mentoring institutions to small businesses. It was interesting to note that the board members or managers did not comment on the need to make the public aware of mentoring services provided by their institutions. This may be because they are part of the initiative, and therefore assume that small businesses know of their institutions' existence. Another possible reason for the board members or managers' silence on this issue could be that they do not have a proper marketing plan to make the public aware of mentoring initiatives. Previous research presents similar findings that many communities are not aware of mentoring facilities available to them. For example, SEDA (2012:91) reports that a lack of awareness of the development support among many SMEs in this country is noted by previous research.

The aspect of planning for practical arrangements such as matching the mentee with the appropriate mentor, scheduling meetings between mentors and mentees, as well as structuring mentoring sessions in appropriate ways was noted as important for the effectiveness of the mentoring process. Therefore, in order to ensure that these practical arrangements are put into place it is recommended that a mentoring evaluation system be put in place. A mentoring evaluation system would help evaluate the effectiveness of mentoring programmes and monitor progress towards achieving mentoring goals and outcomes. By doing this, areas that may need improvement could be identified and dealt with timeously. Therefore it is recommended that an evaluation system and procedures be designed to accommodate evaluation of the mentoring process during and after completion of the mentoring. Hence a mentoring evaluation system is regarded as one of the important aspects relating to the practical arrangements for the mentoring process.

With regard to mentor-mentee matching preferences, all mentee participants in this study did not have a choice in deciding who their mentor would be because they were allocated mentors by the institutions. This is consistent with Munson and McMillen (2008:460) who reported that most of the participants had their mentors arranged for them, while less than half of them had met their mentors through informal interactions such as family, friends and the neighbourhood. Nonetheless, it is advisable that mentoring institutions should have a system of matching mentees with mentors to accommodate pairing preferences of mentees (Garr \& Dewe 2013:251).

Similar to Alonso and Loui (2011) as well as Usmani et al. (2012:283), determining the scheduling of meetings between mentors and mentees is noted as important for effective mentoring in this study. Scheduling of meetings ensures that both mentors and mentees work together to achieve common goals. A survey by Bagramian et al. (2011:293) also reported that mentees prefer to have scheduled meetings with mentors in order to have successful mentoring.

Lastly, regarding the practical arrangements for the mentoring process, the structuring of mentoring sessions is important. It is essential that the manner in which mentoring sessions are structured to address the various mentoring needs of mentees is defined. Varied preferences were reported by mentees: some indicated that they prefer one-on-one mentoring, others indicated a preference for group mentoring, and yet another group indicated that they prefer having both styles of mentoring. Despite these preferences, the majority of mentees were being mentored in one large group per institution at the time of the study, yet their business needs differed from each other. It is important to note that it is often advisable to organise mentees in streams with distinct problems, concerns and goals (Harris, Cheng \& Gorley 2015:195) to achieve the desired outcomes. Even though mentee participants in this study shared a common goal - that of acquiring business management skills - it is equally important to note that their businesses were not all in the same life cycle stage, as indicated by these participants. Therefore, the problems and concerns that these mentees experience may not all be the same. Thus, clearly defining the life cycle stage of a business will assist in structuring mentoring sessions in a manner that will benefit all mentees and make it easier for mentors to focus their guidance.

\section{Contribution}

Previous research on mentoring (Clutterbuck \& Abbott 2012:74; McKevitt \& Marshall 2015:275) states that little information exists on mentoring for small business ownermanagers in South Africa that academic researchers can use. In particular, few studies have been conducted in South Africa on the skills development of black small business owner-managers (see Nkosi et al. 2013). As such, this is the first academic study that has provided valuable insight into the perceptions and experiences of owner-managers during mentoring of black-owned business owner-managers in South Africa. This study is intended to refine mentoring theory in the context of small businesses in South Africa.

Furthermore, previous research on mentoring mainly focused on larger businesses (McKevitt \& Marshall 2015:275) and small businesses operating in Western economies (Lo, Ramayah \& Kui 2013; Mazzarol 2014; Zoogah 2013:20). This study has attempted to address this need for further research into skills development through mentoring, particularly in 
South Africa, as a tool to improve the longevity and success of small businesses in general and black-owned businesses in particular.

The empirical findings of this study reveal various nonrelational conditions that are fundamental for effective mentoring of black small business owner-managers. These conditions are of particular relevance for mentoring institutions as the institutions have control over these conditions and need to put them in place before mentoring processes commence. As such, recommendations and guidelines have been provided to mentoring institutions and other stakeholders during mentoring of small business owner-managers suggesting how to improve the success of specifically black small business owner-managers through the use of mentoring programmes as an important tool for survival.

In conclusion, the findings of this study contribute to the body of knowledge on small businesses by examining the under-researched field of small business mentoring in South Africa. For this reason, many opportunities exist for future research on mentoring of small business owner-managers.

\section{Limitations and future research}

There are limitations with regard to generalising the results obtained from this study as the findings are based on the mentoring perceptions and experiences of participants from four mentoring institutions only. In addition, this study focused only on black owner-managers and therefore limits the capacity to generalise research findings across all small business owner-managers in South Africa. Future research among small businesses from various mentoring institutions across South Africa and small businesses owned by other racial groups in South Africa would add value to this research area. Furthermore, some of the board members or managers of the institutions that participated in this study are also mentors to small business owner-managers. It is likely that their responses may have been biased because of the overlapping roles they play during mentoring processes. Therefore, future research should focus on board members or managers who are not directly involved in the mentoring process.

Despite these limitations, this study makes a significant contribution to the body of knowledge on small businesses towards understanding non-relational conditions required for effective mentoring of black business owner-managers. Therefore, the non-relational conditions identified as important during mentoring of black small business owner-managers could be tested empirically in future research using a quantitative research design and methodology and a relatively larger sample of black small business owner-managers.

\section{Acknowledgements Competing interests}

The authors declare that they have no financial or personal relationships that may have inappropriately influenced them in writing this article.

\section{Authors' contributions}

M.J.M. was the project leader, together with E.V., as well as C.R. who supervised this study from the design until execution.

\section{References}

Adeniran, T. \& Johnston, K.A., 2012, 'Investigating the dynamic capabilities and competitive advantage of South African SMEs', African Journal of Business Management 6(11), 4088-4099.

Allen, T.D., Smith, M.A., Mael, F.A., O’Shea, P.G. \& Eby L.T., 2009, ‘Organization-level mentoring and organizational performance within substance abuse centers', Journal of Management 35(5), 1113-1128. https://doi.org/10.1177/0149206308329969

Alonso, R.A.R. \& Loui, M.C., 2011, 'Work in progress - Exploring the evolution of the mentoring relationship in a summer undergraduate research program', in 41st ASEE/IEEE Frontiers in Education Conference, Rapid City, SD, 12-15 October.

Ayinde, A.T., 2011, 'Mentoring: Does it work?', IFE PsychologIA: An International Journal: Mentoring: A key Issue in Human Resource Management Chapter 1, 1-15.

Bagramian, R.A., Taichman, R.S., McCauley, L., Green, T.G., Inglehart, M.R. \& Habil, P., 2011, 'Mentoring of dental and dental hygiene faculty: A case study', Journal of Dental Education 75(3), 291-299.

Battisti, M., Deakins, D. \& Perry, M., 2013, 'The sustainability of small businesses in recessionary times: Evidence from the strategies of urban and rural small businesses in New Zealand', International Journal of Entrepreneurial Behaviour \& Research 19(1), 72-96. https://doi.org/10.1108/13552551311299260

Bezuidenhout, A. \& Nenungwi, A.L., 2012, 'A competency framework for the small business sector in Johannesburg South Africa', African Journal of Business Management 6(47), 11658-11669. https://doi.org/10.5897/AJBM12.725

Botha, M. \& Esterhuyzen, E., 2012, 'The perceived capabilities and willingness of South African small business owners to act as business mentors', African Journal of Business Management 6(51), 12101-12113.

Botma, Y. \& Roets, L., 2013, 'Ways to improve research outputs of nurse academics in Sub-Saharan Africa', Journal for New Generation Sciences 11(1), 31-41.

Brière, S., Tremblay, M. \& Daou, A., 2015, 'Challenges facing international projects for entrepreneurial development in South Africa', Development Southern Africa 32(6), 711-725. https://doi.org/10.1080/0376835X.2015.1063981

Bryman, A. \& Bell, E., 2011, Business research methods, Oxford, New York.

Chandra, R. \& Aneja, R., 2004, Corporate governance for sustainable environment, Isha Books, New Delhi.

Chimucheka, T. \& Mandipaka, F., 2015, 'Challenges faced by small, medium and micro enterprises in the Nkonkobe Municipality', International Business \& Economics Research Journal 14(2), 309-316.

Cline, M., 2011, 'Paying it forward: The relationship between mentoring and perceived ESE of Jewish South African', unpublished master's dissertation, University of the Witwatersrand, Johannesburg.

Clutterbuck, D. \& Abbott, P., 2012, 'Mentoring as an empowerment tool', Management Today 30(1), 74-77.

Collis, J. \& Hussey, R., 2014, Business research - A practical guide for undergraduate and postgraduate students, 4th edn., Palgrave Macmillan, New York.

Copeland, S.M. \& Calhoun, D.W., 2014, 'Perceptions of mentoring: Examining the experiences of women superintendents', International Journal of Educational experiences of women superintenden
Leadership Preparation 9(2), 28-46.

De Vos, A.S., Strydom, H., Fourché, C.B. \& Delport, C.S.L., 2002, Research at grass roots: For the social sciences and human service professions, Van Schaik Publishers, roots: For the
Cape Town.

Distelberg, B. \& Schwarz, T.V., 2015, 'Mentoring across family-owned businesses', Family Business Review 28(3), 193-210. https://doi.org/10.1177/0894486513511327

Distelberg, B. \& Sorenson, R.L., 2009, 'Updating systems concepts in family businesses: A focus on values, resources flows and adaptability', Family Business Review 22(1) 65-81. https://doi.org/10.1177/0894486508329115

Durbin, S., 2016, Who supports senior women? The role of mentors, Palgrave Macmillan, London.

Eller, L.S., Lev, E.L. \& Feurer, A., 2014, 'Key components of an effective mentoring relationship: A qualitative study', Nurse Education Today 34(5), 815-820. https:// doi.org/10.1016/j.nedt.2013.07.020

Elo, S., Kääriäinen, M., Kanste, O., Pölkki, T., Utriainen, K. \& Kynäs, H., 2014, 'Qualitative content analysis: A focus on trustworthiness', SAGE Open, viewed 15 November 2014, from http://classic.sgo.sagepub.com/content/4/1/2158244014522633

Ensher, E.A. \& Murphy, S.E., 2011, 'The mentoring relationship challenges scale: The impact of mentoring stage, type and gender', Journal of Vocational Behavior 79(1), 253-266. https://doi.org/10.1016/j.jvb.2010.11.008

Fajana, S. \& Gbajumo-Sheriff, M., 2011, 'Mentoring: A human resource tool for achieving entrepreneurial effectiveness', IFE PsychologIA: An International Journal: Mentoring: A key Issue in Human Resource Management 420, 432.

Fatoki, O.O., 2011, 'The impact of human, social and financial capital on the performance of small and medium-sized enterprises (SMEs) in South Africa' Journal of Social Sciences 29(3), 193-204.

Freedman, S., 2009, 'Effective mentoring', IFLA Journal 35(2), 171-182. https://doi. org/10.1177/0340035209105672 
Gallato, C.G., Rashid, S., Suryasaputra, R., Warokka, A., Reamillo, K.A.G. \& Abdullah H.H.B., 2012, 'Fostering niches among SMEs in Malaysia through organizational commitment, leadership, organizational culture and job satisfaction', Journal of Innovation Management in Small \& Medium Enterprises 2012, 1-12. https://doi. org/10.5171/2012.511352

Garr, R.O. \& Dewe, P., 2013, 'A qualitative study of mentoring and career progression among junior medical doctors', International Journal of Medical Education 4 247-252. https://doi.org/10.5116/ijme.5290.ba70

Gentry, W.A., Weber, T.J. \& Sadri, G., 2008, 'Examining career-related mentoring and managerial performance across cultures: A multilevel analysis', Journal of Vocational Behavior 72(2), 241-253. https://doi.org/10.1016/j.jvb.2007.10.014

Gosh, R., 2014, 'Antecedents of mentoring support: A meta-analysis of individual, relational, and structural or organizational factors', Journal of Vocational Behavio 84(3), 367-384. https://doi.org/10.1016/j.jvb.2014.02.009

Harris, B., Cheng, K.F. \& Gorley, C., 2015, 'Benefits and barriers: Case study of a government technology-mediated group mentoring program', Journal of Workplace Learning 27(3), 193-206. https://doi.org/10.1108/JWL-07-2014-0053

Herholdt, J. (ed.), 2012, Mentoring \& coaching: Articles from the human capital review, Knowres Publishing, Randburg.

Horwitz, F.M. \& Jain, H., 2011, 'An assessment of employment equity and broad based black economic empowerment developments in South Africa', Equality, Diversity and Inclusion: An International Journal 30(4), 297-317.

Irwin, D., 2011, 'Learning from business support in Africa', Management Research Review 34(2), 207-220. https://doi.org/10.1108/01409171111102812

Jokelainen, M., Turunen, H., Tossavainen, K., Jamookeeah, D. \& Coco, K., 2011, 'A systematic review of mentoring nursing students in clinical placements', Journal of Clinical Nursing 20(19-20), 2854-2857. https://doi.org/10.1111/j.1365-2702. 2010.03571.x

Kengne, S., 2015, 'Inhibiting factors in the strategic financial management decision making process: Evidence from South African SMMEs', Mediterranean Journal of Social Sciences 6(2), 113-124. https://doi.org/10.5901/mjss.2015.v6n2p113

Lo, M. \& Ramayah, T., 2011, 'Mentoring and job satisfaction in Malaysian SMEs', Journal of Management Development 30(4), 427-440. https://doi.org/10.1108/ 02621711111126891

Lo, M., Ramayah, T. \& Kui, L.C., 2013, 'Mentoring and job satisfaction in Malaysia: A test on small medium enterprises in Malaysia', International Journal of Psychology: A Biopsychosocial Approach/Tarptautinis psichologijos zurnalas: Bioisocialinis poziuris 2013(13), 69-90.

Lucassen, A., Ehlers, K., Grobler, P.J. \& Shezi, A.L., 2013, 'Allele frequency data of 15 qutosomal STR loci in four major population groups of South Africa', International
Journal of Legal Medicine 128(2), 275-276. https://doi.org/10.1007/s00414-013Journal

Mazzarol, T., 2014. How do Australia's universities engage with entrepreneurship and small business?, viewed 07 October 2014, from http://papers.ssrn.com/sol3/ papers.cfm?abstract_id $=2428008$

Mbonyane, B. \& Ladzani, W., 2011, 'Factors that hinder the growth of small businesses in South African townships', European Business Review 23(6), 550-560. https:// doi.org/10.1108/09555341111175390

McFarland, C. \& McConnel, J.K., 2012, 'Small business growth during a recession: Local policy implications', Economic Development Quarterly 27(2), 102-113. https://doi.org/10.1177/0891242412461174

McKevitt, D. \& Marshall, D., 2015, 'The legitimacy of entrepreneurial mentoring', International Journal of Entrepreneurial Behavior \& Research 21(2), 263-280. https://doi.org/10.1108/IJEBR-05-2014-0089

Mentoring and Befriending Foundation, 2009, Funding for mentoring and befriending projects: Challenges and opportunities, viewed 17 November 2014, from http:// www.mandbf.org/wp-content/uploads/2011/03/MBF-Funding-Report-SurveyFINAL.pdf

Miles, D.A., 2013, 'Research in economics, ethnicity and gender: A comparative study on black female-owned and black male-owned business enterprises', Global Business and Economics Research Journal 2(4), 1-23.

Modiba, F.S., Kotzé, D.A. \& Eloff, J., 2012, 'The challenges of accessing information and communication technologies as indicated by women entrepreneurs in Pretoria, South Africa', The International Journal of Interdisciplinary Social Sciences 6(4), 119-130. https://doi.org/10.18848/1833-1882/CGP/v06i04/52059

Munson, M.R. \& McMillen, J.C., 2008, 'Nonkin natural mentors in the lives of older youths in foster care', The Journal of Behavioural Health Services \& Research 35(4), 454-468. https://doi.org/10.1007/s11414-006-9040-4

Mutanda, M., De Beer, M. \& Myers, G.T., 2014, 'The perception of small and micro enterprises in the city of Durban Central Business District (CBD) (Kwazulu-Natal) (KZN) towards financial planning', Mediterranean Journal of Social Sciences $5(6)$ (KZN) towards financial planning', Mediterranean Journ

Myers, M.D., 2013, Qualitative research in business and management, 2nd edn., Sage, New Delhi.

Ndedi, A.A., 2013, 'The incorporation of entrepreneurship in black economic empowerment programmes in South Africa', Journal of Business Management and Economics 4(9), 195-199.

NEF Annual Report, 2014, 'Foreword by the Hon. Minister of Trade and Industry', viewed 27 August 2014, from http://www.thedti.gov.za/parliament/NEF_2.pdf
Neneh, N.B., 2012, 'An exploratory study on entrepreneurial mindset in the small and medium enterprise (SME) sector: A South African perspective on fostering small and medium enterprise (SME) success', African Journal of Business Management and medium enterpr $3364-3372$.

Nkosi, E., Bounds, M. \& Goldman, G., 2013, 'Skills required for the management of black-owned small enterprises in Soweto', Acta Commercii 13(1), 1-10. https:// doi.org/10.4102/ac.v13i1.186

Nyazema, M.M., 2013, 'Developing an empowerment framework for broad-based black economic empowerment in the hotel industry of South Africa', unpublished doctoral thesis, Stellenbosch University, Cape Town.

Offstein, E.H., Shah, A.J. \& Gnyawali, D.R., 2011, 'Effects of CEO-BOD mentoring on firm competitive behaviour', Review of Business 32(1), 75-88.

Oluwatoyin, I.O., 2011, 'Workplace mentoring: Learning and developmental approaches: Chapter 14', IFE PsychologIA: An International Journal Special Issue 1, 169-179.

Olawale, F. \& Garwe, D., 2010, 'Obstacles to the growth of new SMEs in South Africa: A principal component analysis approach', African Journal of Business Management 4(5), 729-738.

Ongori, H. \& Migiro, S.O., 2010, 'Information and communication technologies adoption in SMEs: Literature review', Journal of Chinese Entrepreneurship 2(1), 93-104. https://doi.org/10.1108/17561391011019041

Parak, C. \& Khonje, W.H., 2012, Challenges for SMEs development in small and developing countries, viewed 11 September 2012, from http://www. thecommonwealth.org/files/248999/FileName/SmallStatesDigestlssue22012. pdf\#page $=25$

Preisendörfer, P., Bitz, A. \& Bezuidenhout, F.J., 2012, 'In search of black entrepreneurship: Why is there a lack of entrepreneurial activity among the black population in South Africa?', Journal of Developmental Entrepreneurship 17(1), 125006, 1-18.

Rankhumise, E.M. \& Lehobye, N.M., 2012, 'Success and failure of government-funded businesses: Evidence from a selected entrepreneurial entity in South Africa' African Journal of Business Management 6(16), 5599-5605.

Rogerson, C.M., 2013, 'Improving market access opportunities for urban small, medium and micro-enterprises in South Africa', Urbani Izziv 24(2), 133-143. https://doi.org/10.5379/urbani-izziv-en-2013-24-02-005

Rombeau, J.L., 2010, 'Jonathan E. Rhoads lecture: Mentoring and nutrition care', Journal of Parenteral and Enteral Nutrition 34(1), 89-93. https://doi. org/10.1177/0148607109336884

Shi, L., 2008, Health services research methods, 2nd edn., Thomson, New York.

Slack, R.S., Johnson, C.A., Dodor, B. \& Woods, B., 2013, 'Mentoring "at risk" middle school students: Strategies for effective practice', North Carolina Middle School Association Journal 27(1), 1-11.

Small Enterprise Development Agency (SEDA), 2012, Analysis of the needs, state and performance of small and medium businesses in the agriculture, manufacturing ICT and tourism sectors, viewed 27 March 2014, from http://www.seda.org.za/ Publications/Publications/Analysis $\% 20$ of $\% 20$ the $\% 20$ nenee, $\% 20$ State $\% 20$ and $\% 20$ Performance $\% 20$ of $\% 20$ Small $\% 20$ and $\% 20$ Medim $\% 20$ Businesses $\% 20$ in $\% 20$ the $\% 20$ Agriculture, $\% 20$ Manufacturing, $\% 201$ CT\%20ana\%20Touri.pdf

Smit, Y. \& Watkins, J.A., 2012, 'A literature review of small and medium enterprises (SME) risk management practices in South Africa', African Journal of Business Management 6(21), 6324-6330.

Stam, A.J., 2008, The church in relation to the world, Eburon, Delft.

St-Jean, E. \& Audet, J., 2012, 'The role of mentoring in the learning development of the novice entrepreneur', International Entrepreneurial Management 8, 119-140. the novice entrepreneur', International Entrepre
https://doi.org/10.1007/s11365-009-0130-7

Struwig, F.W. \& Stead, G.B., 2015, Research: Planning, designing and reporting, 2nd edn., Pearson, Cape Town.

Tang, Z., Wu, C., Feng, Z., Zhao, B. \& Yu, W., 2014, 'Improving availability through energysaving optimisation in LEO satellite networks', Information and Communication Technology 8407, 680-689. https://doi.org/10.1007/978-3-642-55032-4_70

Terblanché, S.E., 2011, 'Mentorship a key success factor in sustainable land reform projects in South Africa', South African Journal of Agricultural Extensions 39, 55-74.

Thwala, W.D. \& Mvubu, M., 2008, 'Current challenges and problems facing small and medium size contractors in Swaziland', African Journal of Business Management 2(5), 093-098.

Usmani, A., Rehman, R., Babar, S. \& Afzal, A., 2012, 'Impact of structured meetings on the learning of faculty members', JPMI 26(3), 283-290.

Xavier, W.S. \& Martins, R.S., 2011, 'Logistic strategy and organisational structure in Brazilian small and medium-sized enterprises (SMEs)', Organizations and Markets in Emerging Economies 2(2), 91-116.

Young, K. \& Atkinson, M. (ed.), 2012, Qualitative research and physical culture, Emerald Group Publishing Limited, Bingley.

Zikmund, W.G., Babin, B.J., Carr, J.C. \& Griffin, M., 2013, Business research methods, 9th edn., Cengage Learning, Mason.

Zoogah, D.B., 2013, 'Career motivation, mentoring readiness, and participation in workplace mentoring programs: A cross-cultural study', Journal of African Business 14(1), 19-32. https://doi.org/10.1080/15228916.2013.765310 